\title{
Collective Trauma and National Behavior in Times of Threat-The Israeli Public and the 2014 War in Gaza
}

\author{
Irit Keynan \\ College for Academic Studies, Or Yehuda, Israel
}

\begin{abstract}
This paper analyzes the impact of past trauma on national behavior in times of threat, applying Volkan's (2001, 2004) theory of multigenerational impact of trauma on large groups, and La Capra’s (2014) theory of the use of the concept of individuals' trauma for understanding the behavior of traumatized collectives. The study of the Israeli response to the abduction and murder of three teenagers in summer 2014 is consistent with these theories, and shows how a collective with trauma in its past behaves similarly to a posttraumatic person. The paper contends that due to its traumatic past, the Jewish Israeli public perceived a tragic but limited (from a national security standpoint) hostile action as a grave collective threat, which invoked past demons and brought back existential fears. These feelings were inflamed by the Israeli media and leaders, paving the way for an escalation of the event into an armed battle.
\end{abstract}

Keywords: Trauma, War, conflict, Israel, Palestine, Collective Memory, culture

Bourdieu's theory of habitus (1985) enables us to uncover buried structures of social worlds (Reay, 2004), which have a profound impact on personal and collective views. Looking at Jewish Israeli society through this lens draws attention to the weighty presence of a collective memory of the Holocaust in Israel's life. The Holocaust is innate in Jewish Israelis' way of thinking about themselves and about the outside world (Klar, Schori-Eyal, \& Klar, 2013; Ofer, 2009) as something that "has become durably incorporated in the body in the form of permanent disposition" (Bourdieu, as quoted in Nash, 1999, p. 179). This may explain why the Jewish Israeli public tends to respond to outside threats in a way that reflects posttraumatic symptoms (Keynan, 2015), a known feature in large groups with massive trauma in their past (Volkan, 2001), and that sometimes works as a self-fulfilling prophecy (Moses, 1983). In Israel's seventh decade, the grip of the posttraumatic behavior seems to be stronger than ever. After so many years of persistent conflict, the country can now be described as undergoing what Bar-Tal $(1998,2007)$ calls a culture of conflict—a well-organized system of societal beliefs and attitudes that maintain the collective identity of the group during the intractable conflict's “institutionalization” phase (Oren \& Bar-Tal, 2014). ${ }^{1}$

In Israel's history, there are many examples for conduct reflecting both posttraumatic symptoms and culture of conflict (Bar-Tal, 2007; Keynan, 2009), and both have severe implications for the way Israel deals with outside threats. In this paper, I focus on the posttraumatic behavior, which Volkan $(2001,2004)$ describes

Irit Keynan, Ph.D., Senior Lecturer, College for Academic Studies.

Correspondence concerning this article should be addressed to Irit keynan, Ph.D., 2 Hayotzrim st., Or Yehuda, 60218, Israel.

${ }^{1}$ Oren and Bar-Tal (2014) define the "institutionalization” phase as the conflict's climax phase, when neither side can win and achieve its goals, and at the same time, neither is willing to compromise in order to settle it peacefully. 
as the long-term multi-generational imprint of trauma on traumatized groups; and I use LaCapra's concept (2014), of the use of theories of individual trauma for understanding social and political processes of traumatized societies. My main argument is that based on its traumatic past and habitus, the Jewish Israeli public perceives individual hostile actions as a grave collective threat, which invokes past demons and brings back old existential fears. These feelings are inflamed by the media and often misused by leaders, thus paving the way for the situation to deteriorate into an armed battle.

On June 12, 2014, Hamas terrorists abducted and murdered three Jewish Israeli teenagers ${ }^{2}$. During the 18 days between the abduction and the discovery of the teenagers' bodies, the abduction and the search operation dominated Israel's media and public discourse, in a way that reflects post-traumatic characteristics. Political leaders, especially Prime Minister Benjamin Netanyahu, as well as religious leaders intensified the common perception of an immediate collective, severe threat, and the political opposition, albeit in a more moderate way, echoed this alarming message (Mualem, 2014). As the tension escalated, Hamas began firing a growing number of rockets from the Gaza strip (under Hamas rule since Israel's withdrawal on 2005) at civilian targets in southern Israel, while its militia men attempted to infiltrate Israeli towns via underground tunnels. These events were the prelude to what developed into a 51-day war in Gaza, during which Israel used massive force.

The Israeli response to the abduction and the murder of the three teenagers is used here as a test case to explore the argument that Israelis respond to hostile acts in a posttraumatic manner.

The paper is organized as follows: After describing the events between the abduction and the beginning of the war in Gaza, it gives examples of conspicuously inflammatory vocabulary used by political and religious leaders during the crisis. It then analyzes the role of the media in delivering the message of an acute collective threat. This is followed by an exploration of the idea of societal posttraumatic stress disorder (PTSD) in large groups with trauma in their past, and its expressions in Israel. The paper ends with a summary and conclusions.

\section{From the Abduction and the Murder to the War in Gaza}

The abduction and later murder of the three teenagers was undoubtedly tremendously traumatic for their families and loved ones. Jewish Israeli society however, perceived it as a national trauma that disrupted and captured the attention of the whole nation. Religious and political leaders arranged public prayers and huge rallies, with tens of thousands of participants (Magnezi \& Morag, 2014), and the Israeli parliament (Knesset) held a public prayer for the safe return of the boys ${ }^{3}$. The three major Israeli television channels suspended their regular schedule and moved to an emergency mode, with continuous coverage of every detail of the search operation, emotional reports about the teenagers' families, and live interpretations of every fact or rumor pertaining to the abduction, no matter how minor. Israelis changed their regular media-consuming habits, their attention focused on the ongoing "breaking news," obsessively listening to every detail. Whereas this reflected the Israelis' high vulnerability to any loss of life at the hand of enemies, it was also a result of how it was delivered—as a trauma shared with others (Neal, 2005), and a threat to the whole nation.

The army held daily press conferences with senior army generals-even when there was no progress in the search efforts, and often with the participation of the Chief of Staff and the Minister of Defense. The Prime Minister delivered frequent messages via television and through his Facebook account. All this together

\footnotetext{
${ }^{2}$ A Hamas senior official confirmed [on August 20] that the abduction and murder was carried out by the Hamas military wing-Izz ad-Din al-Qassam Brigades.

3 June 16, 2014, Press release, the Knesset, http://main.knesset.gov.il/News/PressReleases/Pages/press16614a.aspx.
} 
increased the tension and created an atmosphere of a national emergency. Israeli daily newspapers (except Haaretz, the Israeli parallel to the New York Times) printed huge headlines, which provided little information but let the public know how it was expected to feel and behave: united, embracing the families, praying for "our" (all Israelis) children (Tausig, 2014), and having faith in the security forces. As the search operation continued to show no success, and the fear for the teenagers' fate deepened, tension escalated.

Led by the Prime Minister, politicians delivered ardent speeches criticizing Mahmud Abas (president of the Palestinian Authority) for formulating a unity government with Hamas (the unity later collapsed), which Israel saw as enabling Hamas to initiate terror from the West Bank, and warning the latter of retaliation. As will be shown in the next section, the speakers framed the abduction as another proof of anti-Semitism, as a manifestation of the old familiar persecutions against the Jews.

During the search, the IDF arrested 400 Hamas activists in the West Bank and confiscated their weapons. Hamas threatened to carry out more attacks, while firing a growing number of rockets onto civilian targets inside Israel, exacerbating the anxiety and anger among Israelis. Gradually the Israeli public became more and more edgy, and began to accept the idea that a military response was unavoidable. What began as a limited terror act deteriorated into 51 days of war between Israel and Hamas in Gaza (called in Israel "Operation Protective Edge”). For over seven weeks, Hamas fired 4,000 rockets at Israeli cities and towns, and used underground tunnels through which militia fighters armed with explosives attempted to infiltrate into the midst of civilian towns in southern Israel. In retaliation, Israel increased the force it was using by deploying airstrikes and ground forces. Thanks to Iron Dome (a mobile air defense system), Hamas rockets failed to cause serious damage to the Israeli civilian population. In Gaza, however, 4,000 buildings were heavily damaged or destroyed. The war ended on August 26, 2014 with a death toll of 70 Israelis (5 civilians and 65 soldiers) and 2,203 Palestinians (about one-third of them civilians).

\section{Conspicuous Vocabulary Used by Political and Religious Leaders During the Crisis}

\section{Prime Minister Netanyahu}

Influenced by his father, a right-wing historian, Netanyahu is convinced that Israel's future is constantly at risk (Mitchell, 2015; Kimhi, 2001), and he repeatedly uses traumatic symbols from the Jewish people's past to deliver messages concerning Israel's security. ${ }^{4}$ One such symbol, which he used in his speech at a special cabinet meeting on the day the bodies of the three teenagers were found, is of special interest in the present context. "Fit revenge for blood of small children on earth, the devil has yet to bring forth", he quoted. ${ }^{5}$ The words are taken from the poem "Al Hashchita” ("In the City of Slaughter"), written by the renowned Jewish poet Chaim Nachman Bialik (1873-1934), after the Kishinev Pogrom in 1903 (now the Ukraine, but at the time a part of Russia). During the pogrom, which went on uninterrupted by local police for three consecutive days, 47 Jews were killed, hundreds were wounded, dozens of women were brutally raped, and babies were torn from their parents' arms and murdered. In addition, hundreds of houses were destroyed and hundreds stores were looted (for details about the pogroms, see Shapira, 1999). While the poem mourns the dead, the raped, and the

\footnotetext{
${ }^{4}$ Conspicuous example are his speeches concerning the debate over Iran's nuclear weapon. See Hirschberg, P. (November 14, 2006). Netanyahu: It’s 1938 and Iran Is Germany; Ahmadinejad Is Preparing Another Holocaust. Haaretz. http://goo.gl/Q1HqAZ; Rabinovitch, A. (April, 18, 2012). Netanyahu defends comparison of Iran to Nazi Holocaust. Reuters. http://goo.gl/CSWs77; Gandar, K. (April 16, 2015). Israeli Prime Minister Benjamin Netanyahu compares Iran to the Nazis. Independent. http://goo.gl/eymJUB; and many more.

${ }^{5}$ Cited in Walla news, June 30, 2014, http://news.walla.co.il/item/2760056.
} 
wounded, it also criticizes the Jewish passivity and lack of self-defense, and has been associated ever since with the emergence of Jewish self-defense movements, nonexistent in the diaspora until that time (Shapira, 2005). Netanyahu's choice of this poem therefore is not accidental. By using it, he achieved two goals at the same time: he reminded Israelis of the brutality once perpetrated against innocent Jewish children, connecting the past with the present, and he revived the vow of "never again" (never again will the Jews be victims), which became especially significant after the Holocaust and has been a prevailing Israeli motto ever since ${ }^{6}$.

By using this poem in July 2014, Netanyahu framed the murder of the three teenagers in a far wider context than that of the Israeli-Palestinian conflict, emphasizing its connection to the long history of Jewish suffering, suggesting that the maliciousness of the murderers was derived from hatred for any Jew, and not from the political conflict. This is a known mechanism of reactivating traumatic memories, encouraging what has been termed time collapse (Volkan, 2001; Bar-Tal, 2013) - a confusion between past trauma and the present situation, and a feeling that the nation is facing a similar threat to that which it faced in the past. In this case, it reactivated the Jewish collective memory of helplessness against brutal attackers. Reviving the collective memory is also known to be used to prepare the public for a massive military action, far more than the circumstances require (Kaufman, 2006). By doing this, Netanyahu revived the Israelis' assertive way of coping with threats, and assured public support for a forceful military response.

\section{Chief Rabbi David Lao}

"The Jewish People all over the world is shocked by the abominable murder of the boys. They were murdered as martyrs only for being Jews, and they are joining the chain of our people's sacred and pure martyrs over all the painful history of the Jewish people"7. This quotation delivers the same motif that Netanyahu used. The murder is not based in the current conflict, but is a part of the two millennia of hatred and persecution against the Jews. Here, too, the element of time collapse is emphasized, and the traumatic past of the Jewish people is brought into the present. Like Netanyahu, Rabbi Lao expands the scope of the event, and presents it as an offense against every Jew, wherever she or he may be, not just against Israelis, and not as part of an intractable conflict with the Palestinians. This message aligns with another message by Netanyahu delivered to the public, via his cited talk with bereaved families of Israeli soldiers and civilians killed in the conflict. In this talk, he said that "in the long war against our enemies, one should first and foremost know the truth about the history of the Jewish People, and then to struggle and fight for this truth” (Netanyahu's Facebook, July 7, 2014). In fact, such statements confirm the common Israeli concept of "unifying the enemy" (Bar-Tal, 2007), namely the belief that although the enemy's identity has changed over the years, the Jewish people still face the same existential danger it did during the Holocaust and all through the 2,000 years of persecution.

Based on this belief, most Israelis—religious and non-religious alike- have been deeply affected by the above statements and by many other similar ones made by politicians, as they give meaning to their own sense of overwhelming threat, which they believe always awaits the Jews. The majority of Jewish Israelis thus yielded to the collective belief of the impossibility of ever solving the conflict (Bar-Tal, Halperin, \& Pliskin, 2011), and therefore many of them approved of the government's decision to send the army into Gaza. Moreover, those who did object and called to stop the war or at least to minimize the scope of casualties on the

\footnotetext{
${ }^{6}$ In a similar rhetoric, this vow was frequently used by Prime Minister Menachem Begin (1977-1983) in his time, especially during the first Lebanon war 1982 (Keynan, 2009).

${ }^{7}$ Quoted in Haaretz, June 30, 2014. http://goo.gl/8zg4iL.
} 
Palestinian side, were vulgarly attacked and shamed in the social media (Lev-On, 2016), and sometimes even physically attacked during demonstrations against the war (see, for example, Khuri, Rinat, \& Arad, 2014).

\section{The Media}

Terrorist attacks have a particular nature: they are sudden, overwhelming, and one does not know how to avoid them (Somer \& Bleich, 2005). Such attacks undermine an individual's basic assumptions about safety in her/his environment, residence, and everyday life, and give rise to serious adjustment difficulties. Studies have shown that, in contrast to trauma caused by natural and technological disasters, trauma induced by terrorist attacks is particularly profound (Tuval-Mashiah \& Shalev, 2005). The attacks occur repeatedly yet randomly - they frustrate individuals' attempts to develop a forecasting model or to determine the most effective means of avoiding them in the course of one's daily activities (Tuval-Mashiah \& Shalev, 2005). Trauma of this kind, is produced by exposure to exceptionally threatening and shocking scenes, combined with the knowledge that the same traumatic elements are likely to recur at an unknown time and place. Yet, in a country like Israel that is used to long periods of terror attacks, the anxiety level of the public is not always the same, but depends also on the frequency of their exposure to media coverage, and the nature of the messages delivered by leaders and commentators.

Research findings are not all in agreement on the issue of whether or not exposure to constant media coverage of fearful and traumatic events may cause full-fledged PTSD (Bodas, Siman-Tov, Peleg, \& Solomon, 2015). Some researchers indicate findings that do not support a strong link between such exposure and the development of psychopathology (Galea and colleagues as quoted in Bodas, Siman-Tov, Peleg, \& Solomon, 2015). Other researchers suggest the opposite, that the impact of televised coverage of terror is so strong that the probability of developing PTSD by people in the highest third of continuous coverage viewing is almost double than that of those in the lowest third of frequent watching (Ahern, Galea, Resnik, and Blahov, 2005 as quoted in Bodas, Siman-Tov, Peleg, \& Solomon, 2015. Their findings about the 9/11 Twin Towers attack in New York City show 1.66 times greater odds). The debate, however, is about the extent of the stress caused by the media, and not on the fact that the constant broadcasting of alarming information in times of threat creates grave emotional stress. In a study about the weeks following the war in Gaza (Protective Edge), Bodas, Siman-Tov, Peleg, Solomon and colleagues (2015) found anxiety symptoms among Jewish Israeli adults to be associated with increased viewing patterns of televised traumatic contents. Such stress has been shown to reactivate past trauma and create a time collapse (Volkan, 2001), exacerbating the sense of helplessness, and reinforcing the public adherence to what gives a false sense of security: launching war and using as much force as possible. Israeli media in the summer 2014 was not only reporting the traumatizing pictures and speeches, it also echoed the message of the government, emphasizing and enhancing the alarming messages, and refrained from bringing opposing voices (Negbi, 2015).

Journalistic freedom in wars is compromised everywhere (Knightley, 2004). In traumatized groups, however, any attempt to challenge the "consensus," and especially to doubt the gravity of the present threat or the need to use massive force, is perceived as harming the nation's unity and as a hostile provocation, if not treason. In the face of the collective threat, it is demanded that all group's members, including the media, show unity and align with the government. Criticism or objection to the "consensus" is firmly rejected. Thus the chief director of Walla, a popular news internet site, declared, when explaining his site's reporting policy, that he is "first of all Jewish and Israeli and only then a journalist" (Negbi, 2015, p. 161). The Israeli Institute for 
Democracy found that $58.4 \%$ of Israeli Jews and $44.5 \%$ of Israeli Arabs supported limitation of the freedom to criticize those leading the war (Negbi, 2015). In the social media, an unprecedented number of abusive and racist expressions were registered against anyone perceived as "supporting the enemy," even if they were only expressing sadness for the dead civilians in Gaza (Coalition against Racism in Israel, 2015).

Emotionally laden, threatening information is known to increase the public's probability of supporting the policies advocated by political leaders (Gadarian, 2010). Nevertheless, the massive attacks against those who think differently require further explanation, and this turns the attention back to trauma.

\section{Societal PTSD}

National trauma disturbs all segments of society, completely disrupting the social system (Erikson, 1995), while an individual trauma harms the life of the individual victim (American Psychiatric Association, 2013). At the same time, however, individual trauma affects not only those afflicted with it, but also their spouse and children; entire families may suffer from secondary trauma (Lahav, Kanat-Maymon, \& Solomon, 2015; Waysman, Mikulincer, Solomon, \& Weisenberg, 1993). When there are many cases of personal trauma with a similar underlying cause, the repercussions of trauma — extending outward in ever-widening circles—reach the entire national community, and the scars borne by individuals may merge into a whole that is greater than the sum of the suffering individuals, producing a group ethos that bears the hallmarks of trauma (Erikson, 1995). Moreover, collectives with massive trauma in their past bequeath to their descendants a sense of degradation and continuous threat. The following generations, therefore, see it as their duty to reject and rehabilitate the humiliated image of the traumatized past generations, and to transform the past passivity and helplessness into an active and assertive, often exaggerated response to any danger (Volkan, 2001). This unconscious mechanism, a known symptom of PTSD in traumatized individuals (Finley, 2011), is also a characteristic of traumatized groups. For Israelis, it has been part of their coping system since the country's birth (Milgram, 1994). Other similarities pertain to the power of collective trauma to undermine society's sense of stability, just as it does in the case of individual trauma, and to perpetuate feelings of endangerment, disorder, and profound fracture (Bodnar, 1998).

Whereas the national psyche is not identical to an individual one, the similarities offer a conceptual framework that is valuable for the analysis of socio-political processes (LaCapra, 2014). In fact, it is possible to think of collective trauma as a "societal PTSD" that strikes an entire community and affects all of its members (Elliott, Bishop, \& Stokes, 2004). This may explain why nations sometimes react in a way that is reminiscent of a national trauma, while the trigger event may actually have affected only a few individuals.

When terror is involved, the reactivation of the collective trauma can be especially harsh, because, as brought above, terror attacks may cause a heavy emotional threat to develop in any society. Galea and Resnik (2005) claimed that terror events are "shared traumatic experiences that may result in substantial psychological consequences in the general public" (p. 107). In traumatized societies, which at the same time are mired in a current protracted conflict, the impact of terror may be even stronger, since the historical continuum from the traumatic national past to the contemporary conflict fuels a vicious cycle. The collective memory justifies continuing the conflict, while the conflict engenders yet another menacing collective memory, and so on (Keynan, 2009). In such a perpetual process, representations of the distant past blend with the continually emerging new harmful memories, and together they flood the national psyche with existential fears and doubts over the possibility of ever escaping the cycle of violence and terror. 


\section{Summary and Conclusions}

Group members tend to experience feelings based on their group-based emotional preferences (Porat, Halperin, \& Tamir, 2016), which in traumatized societies, such as in Israel, are those of fear and conviction of the imminent possibility of repetition of past traumas.

In the summer 2014, Israelis experienced anxiety evolving both from the abduction of the teenagers and the terror threat of the underground tunnels, exacerbated by the way it was delivered to the public by religious and political leaders and by the media, and by the deeper and wider symptoms of societal PTSD. In such an atmosphere, outside threats reactivate past traumas, a process, which strengthens the commitment of all parts of society to its defense (Volkan, 2001). This may explain why the Israeli public, usually highly sensitive to any risk to a soldier's life, accepted the government decision to go to war, despite the risks to its young combatants. At the same time, although carrying out air strikes and the use of excessive force against Gaza has been widely disputed among Israelis, in the face of what seemed to be a potentially recurring past trauma, the majority felt that all means of self-defense are legitimate. Just as posttraumatic individuals tend to respond to actual and perceived threats with a disproportional aggressiveness (Keynan, 2015), so do traumatized groups: when they sense an immediate threat, they tend to agree to the use of disproportional retaliation against the perceived aggressor (Kaufman, 2006).

In June-July 2014, the fear of a major threat, originally shared by most Israelis, became greater when Hamas militants tried to infiltrate southern Israeli towns via underground tunnels. This may explain why people with moderate views accepted the need for a full-scale attack on Gaza, and why the main opposition parties did not protest. Most members of the Knesset supported the war, and the chair of the opposition, Itzhak Hezog, said: "In this matter there is no controversy between coalition and opposition. We are having a justified struggle for the future of Israel and the Jewish people” (Vilf, 2014).

Although the war did not bring about the destruction of Hamas as Netanyahu had promised, public opinion continued to support the war, and despite the relatively high number of soldiers killed, all polls showed public support of the war. In addition, the public atmosphere increasingly became more and more hostile against any internal criticism of the war.

Victims of genocide or of extreme violence tend to transfigure the trauma they suffered into the sacred (LaCapra, 2014). This traumatropism, to use LaCapra's (2014) term, prevents trauma from going through a healing process, and instead it plants the trauma in the group's mind, as a kind of stigmata, demanding endless melancholy and grieving, while attempts to weaken its grip over the nation's psyche is perceived as profane (LaCapra, 2014). Hence, politicians' metaphors taken from the traumatic past create a public atmosphere that does not allow questioning the realistic dimensions of the threat, or criticism of the aggressive solution chosen. This process may explain the above-mentioned response of the Israeli political opposition. It may also explain why the majority of the public in the summer 2014 identified with Netanyahu's message of an imperative need for national unity in the face of the danger. "At this time," he declared, "there is an impressive unity among Israeli citizens, as it should be amid a people who is fighting for its life against a bloodthirsty enemy" (quoted in Yaari \& Dvori, June 19, 2014). The media accepted his call, emphasizing unity and reducing reports on controversies, while abstaining from its duty to bring to the public the arguments of those questioning the war (Negbi, 2015). Right-wing supporters took this stance further, brutally and aggressively demanding from all segments of society to align with government policy and to identify with the conviction that the war was just 
and inevitable. Any other view was declared profane, and those expressing opposing views were libeled as traitors.

Israeli society is a clear example for the theories discussed in this paper, and the war in summer 2014 is a clear example for the traumatic mechanisms that motivate Jewish Israelis in times of threat. The close relationship between the personal stories of trauma casualties and the overarching story of the national group has developed into a traumatic ethos in Israel, and this ethos has been dictating the county's life since its establishment (Keynan, 2015); a traumatic habitus, which has shaped the entire national mode of thought and conduct. Most Israelis see and interpret every political event, let alone any hostilities, through these traumatic lenses. It is not surprising, then, that a personal trauma resulting from the conflict, such as the abduction of the three teenagers, is shared by the whole nation, not only as social support and identifying with the families' sorrow, but also as a common threat.

Leaders often misuse the collective fears and traumatic memories of their nations, whether to strengthen their leadership or because they themselves are part of the same traumatic ethos. In the summer of 2014, Israelis responded in a posttraumatic way, and cooperated with the politicians' framing of the teenagers' abduction as a huge national threat. Putting the event into this framework reactivated posttraumatic symptoms and led Israelis to identify with the government's policy, which led to excessive loss of life.

Whereas this paper studies the traumatic behavior of the Israeli side, in future research it would be interesting to examine whether on the Palestinian side a similar behavior may be detected.

\section{References}

American Psychiatric Association. (2013). Diagnostic and statistical manual of mental disorders. (DSM-5®). Arlington, VA: American Psychiatric Association Publishing.

Bar-Tal, D. (1998). Societal beliefs in times of intractable conflict: The Israeli case. International Journal of Conflict Management, 9(1), 22-50.

Bar-Tal, D. (2007). Living with the conflict: Socio-psychological analysis of the Israeli-Jewish society. Jerusalem, Israel: Carmel. (Hebrew).

Bar-Tal, D. (2013). Intractable conflicts: Socio-psychological foundations and dynamics. Cambridge, UK: Cambridge University Press.

Bar-Tal, D., Halperin, E., \& Pliskin, R. (2011). Why is it so difficult to resolve intractable conflicts peacefully? A sociopsychological explanation. In M. Galluccio (Ed.), Handbook of international negotiation: Interpersonal, intercultural, and diplomatic perspectives. DOI 10.1007/978-3-319-10687-8_7

Bodas, M., Siman-Tov, M., Peleg, K., \& Solomon, Z. (2015). Anxiety-inducing media: the effect of constant news broadcasting on the well-being of Israeli television viewers. Psychiatry, 78(3), 265-276.

Bodnar, J. (1998). National trauma and collective memory (book review). H-Net Reviews in the Humanities \& Social Sciences.

Bourdieu, P. (1985). The genesis of the concepts of habitus and field. Sociocriticism, 2(2), 11-24.

Coalition against Racism in Israel. (2015). Racism during operation protective edge. Retrieved from http://www.fightracism.org/Article.asp?aid=527

Elliott, M., Bishop, K., \& Stokes, P. (2004). Societal PTSD? Historic shock in Northern Ireland. Psychotherapy and Politics International, 2(1), 1-15.

Erikson, K. (1995). Notes on trauma and community. In C. Caruth (Ed.), Trauma: Explorations in memory. Baltimore, MD: Johns Hopkins University Press.

Finley, E. (2011). Fields of combat. Understanding PTSD among Veterans of Iraq and Afghanistan. Ithaca, NY: Cornell University Press.

Gadarian, S. K. (2010). The politics of threat: How terrorism news shapes foreign policy attitudes. The Journal of Politics, 72(02), 469-483.

Galea, S., \& Resnick, H. (2005). Posttraumatic stress disorder in the general population after mass terrorist incidents: Considerations about the nature of exposure. CNS Spectrums, 10(02), 107-115. 
Kaufman, S. J. (2006). Symbolic politics or rational choice? Testing theories of extreme ethnic violence. International Security, $30(4), 45-86$.

Keynan, I. (2009). Collective memory and intergroup leadership-Israel as a case study. In T. L. Pittinsky (Ed.), Crossing the divide: Intergroup leadership in a world of difference (1st ed., pp. 219-230). Boston, MA: Harvard Business Press.

Keynan, I. (2015). Psychological war trauma and society: Like a hidden wound. London, UK \& New York, NY: Routledge.

Khuri, J., Rinat, T., \& Arad, R. C. (2014, July 14). Hundreds of right wing activists attacked left demonstrator in Haifa; Clashes also in Tel Aviv. Haaretz.

Kimhi, S. (2001). Benjamin Netanyahu: A psychological profile using behavior analysis. Profiling Political Leaders: Cross-Cultural Studies of Personality and Behavior, 149-164.

Klar, Y., Schori-Eyal, N., \& Klar, Y. (2013). The "Never Again” state of Israel: The emergence of the Holocaust as a core feature of Israeli identity and its four incongruent voices. Journal of Social Issues, 69(1), 125-143.

Knightley, P. (2004). The first casualty: The war correspondent as hero and myth-maker from the Crimea to Iraq. Baltimore, MD: Johns Hopkins University Press.

Lahav, Y., Kanat-Maymon, Y., \& Solomon, Z. (2015). Secondary traumatization and attachment among wives of former POWs: A longitudinal study. Attachment \& Human Development, 1-13.

Lev-On, A. (2016). The non-social web? Framing Facebook in the Israeli mainstream newspaper during operation protective edge. ISOC-IL, Israeli Internet Association. Retrieved from https://www.isoc.org.il/magazine/magazine16_1.html

LaCapra, D. (2014). Writing history, writing trauma. Baltimore, MD: Johns Hopkins University Press.

Magnezi, A., \& Morag, G. (June, 15, 2014). Rabbi Lao, not to wait like we did with Gilad Shalit. Ynet. Retrieved June 15, 2014, from http://www.ynet.co.il/articles/0,7340,L-4530676,00.html

Milgram, N. (1994). Psychological research in Israel during the Gulf War. Psychology, 4, 1-2, 7-19. (Hebrew)

Mitchell, T. G. (2015). Likud leaders: The lives and careers of Menachem Begin, Yitzhak Shamir, Benjamin Netanyahu and Ariel Sharon. Jefferson, NC: McFarland.

Moses, R. (1983). Emotional response to stress in Israel: A psychoanalytic perspective. Stress in Israel, 114-137.

Mualem, M. (2014, August 5). Herzog stands by Netanyahu on Gaza. Almonitor. Retrieved from http://goo.gl/NiArjB

Nash, R. (1999). Bourdieu, "habitus", and educational research: Is it all worth the candle? British Journal of Sociology of Education, 20(2), 175-187, DOI: 10.1080/01425699995399

Neal, A. G. (2005). National trauma and collective memory: Extraordinary events in the American experience. Armonk, NY: M. E. Sharpe Publishers.

Negbi, M. (2015). The limits of freedom of journalism in times of war as reflected in covering Protective Edge operation. Law and Military: Journal of the Military Advocacy: 21A, 157-181. (Hebrew)

Ofer, D. (2009). The past that does not pass: Israelis and Holocaust memory. Israel Studies, 14(1), 1-35.

Oren, N., \& Bar-Tal, D. (2014). Collective identity and intractable conflict. In R. Jaspal and G. M. Breakwell (Eds.), Identity process theory: Identity, social action and social change. Cambridge University Press.

Porat, R., Halperin, E., \& Tamir, M. (2016). What we want is what we get: Group-based emotional preferences and conflict resolution. Journal of Personality and Social Psychology, 110(2), 167.

Reay, D. (2004). "It's all becoming a habitus": Beyond the habitual use of habitus in educational research. British Journal of Sociology of Education, 25(4), 431-444.

Shapira, A. (1999). Land and power: The Zionist resort to force, 1881-1948. Stanford, CA: Stanford University Press.

Shapira, A. (2005). In the city of slaughter “versus” he told her. Prooftexts, 25(1\&2), 86-102.

Somer, E., \& Bleich, A. (2005). Stress in a population under prolonged terrorist attack: Identification, characterization and treatment challenges. In E. Somer and A. Bleich (Eds.), Mental health in terror's shadow: The Israeli experience. Tel Aviv, Israel: Ramot. (Hebrew)

Tausig, S. (2014, June 18). Everything is legal. The Seventh Eye, Internet magazine for media review. Retrieved from http://www.the7eye.org.il/113480

Tuval-Mashiah, R., \& Shalev, R. (2005). The epidemiology of mental responses to continuous terrorism among adults in Israel. In E. Somer and A. Bleich (Eds.), Mental health in terror's shadow: The Israeli experience. Tel Aviv, Israel: Ramot. (Hebrew)

Vilf, R. (2014, July 29). Herzog: The war in Gaza is just; there is no dispute on that. NRG. Retrieved July 29, 2014, from http://www.nrg.co.il/online/1/ART2/602/406.html

Volkan, V. D. (2001). Transgenerational transmissions and chosen traumas: An aspect of large-group identity. Group Analysis, 34(1), 79-97. 
Volkan, V. D. (2004). Blind trust: Large groups and their leaders in times of crisis and terror. Charlottesville, VA: Pitchstone Publishing.

Waysman, M., Mikulincer, M., Solomon, Z., \& Weisenberg, M. (1993). Secondary traumatization among wives of posttraumatic combat veterans: A family typology. Journal of Family Psychology, 7(1), 104.

Yaari, A., \& Dvori, N. (June 19, 2014). Netanyahu on the abductees' case: “We know now more than a few days ago”, Mako, Channel 2. Retrieved June 19, 2014, from http://goo.gl/eaQ96Q 